\title{
Using the Community Engagement Framework to Understand and Assess EJ-Related Research Efforts
}

\author{
Dana H. Z. Williamson
}

Citation: Williamson, D.H.Z. Using the Community Engagement

Framework to Understand and

Assess EJ-Related Research Efforts.

Sustainability 2022, 14, 2809. https://

doi.org/10.3390/su14052809

Academic Editor: John T. Cooper

Received: 1 February 2022

Accepted: 24 February 2022

Published: 28 February 2022

Publisher's Note: MDPI stays neutral with regard to jurisdictional claims in published maps and institutional affiliations.

Copyright: (C) 2022 by the author. Licensee MDPI, Basel, Switzerland. This article is an open access article distributed under the terms and conditions of the Creative Commons Attribution (CC BY) license (https:/ / creativecommons.org/licenses/by/ $4.0 /)$.
Association of Schools and Programs of Public Health (ASPPH), Environmental Health Fellow Hosted at Scientific Integrity Program, Office of Science Advisor and Policy Engagement (OSAPE), Office of Research and Development (ORD), U.S. Environmental Protection Agency (USEPA), Washington, DC 20004, USA; williamson.dana@epa.gov; Tel.: +1-404-594-1156

\begin{abstract}
Within an environmental justice frame, capacity-building has been an important component of efforts to address health disparities at the policy, system, and environment levels. While the literature is replete with studies that discuss the necessity of collective action as a means to generate power to overcome inequities, limited attention has been given to the structure of these efforts to build capacity and challenge environmental injustices. This study applies the community engagement continuum as a framework for understanding the scope of capacity-building strategies and the manner in which research investigators engage with their intended target community. Paired teams of independent analysts screened articles for relevance $(n=8452)$, identified records for content abstraction $(n=163)$, and characterized relevant studies $(n=58)$. Many articles discussed community engagement as being either collaborative or shared leadership ( $n=32,55.2 \%)$. While the most commonly used capacity-building strategies were organizing/social action (58.6\%) and CBPR (50\%), few studies were able to make an environmental impact $(n=23 ; 39.7 \%)$, and fewer had a direct legislative policy-related outcome $(n=13 ; 22.4 \%)$. This review identifies levels of collaborative involvement and strategic approaches used for strengthening community capacity in efforts of making transformative policy, systems, and environmental change.
\end{abstract}

Keywords: community engagement; community capacity; environmental justice; praxis; mobilization; empowerment; social justice; advocacy; equity

\section{Introduction}

Explicit and implicit discrimination in environmental policymaking, targeting of communities of color for toxic waste facilities, and under-resourcing and overburdening of communities have been collectively termed environmental racism [1] and have plagued the United States for decades [2]. The environmental justice (EJ) movement demands that "everyone is entitled to equal protection and enforcement of environmental health, housing, land use, transportation, energy and civil rights laws and regulations" [3], and over the past 30 years, has progressed to incorporate all aspects of "where we live, work, play, and pray" [3]. Additionally, EJ has expanded to a framework for organizing [4-9] to include but not be limited to food justice [10], green space [11], climate change [12], immigrant and indigenous rights [13] and refurbishment of brownfields [14]. The EJ framework delineates the necessity of centering the experiences of low-income groups, communities of color, and underrepresented groups to reduce the disproportionate exposure to adverse environmental impacts and hazards.

The patterning of environmental inequity has received great attention [15] and many studies have further highlighted the pervasive nature of race as the variable most consistently associated with higher risk and proximity to environmental hazards. Accordingly, overburdened communities have been a focus area for many institutions, foundation initiatives, and practitioners in the fields of public health, public policy, urban planning, 
economics, and social work. Numerous empirical articles have cited discriminatory practices and the inequities with toxic waste distribution among low-income groups, indigenous people, and communities of color [3,15-24]. Broadly, these discussions within the scientific literature appear to fall into three categories: (1) characterizing environmental exposures among marginalized communities [2,25-31]; (2) epidemiologic studies linking exposures to health outcomes in low-income and racial ethnic populations [32-35]; and (3) intervention studies that seek to mitigate risk [36-39]. Across these categories, the necessity of building capacity and the need to engage community in addressing local environmental concerns/inequities have often been discussed. In particular, the intentional and meaningful practice of community-based participatory research (CBPR) has been employed by many academics [40-57]. However, while CBPR is a model strategy for engagement, it is only one equity-based approach, as the process of capacity-building centers on community empowerment, mobilization, and actions needed to accomplish goals, and extends far beyond this community-academic partnership structure.

The literature is replete with studies that discuss the necessity of collective action as a means to generate power to overcome social injustice [58]. This systematic scoping review provides an opportunity to understand decades of community-engaged partnerships and community-led efforts that have been employed to reduce environmental inequities. The theory of community capacity is used as an organizational framework, for understanding patterns for community building [59] and strategies to enhance a community's ability to address environmental health concerns [60]. The community engagement continuum is also incorporated into this discussion to provide clarity on the levels of collaborative involvement and communication to better understand community-partnership relations in addressing environmental concerns. This review also serves to identify trends of successful community change efforts and allows for the identification of novel approaches in making transformative environmental and policy change.

\section{Materials and Methods}

Research methods for the systematic search and scoping review are described in Williamson et al. [61]. In brief, 58 peer-reviewed studies published from January 1986 to March 2018 are used in the review and detail community-academic partnerships and community-engaged efforts employed to address environmental inequities related to air, land, and water pollution in the United States (see Appendix A Figure A1). Included studies were published in English and considered eligible if the study detailed the use of any variation of community-engaged methods and included: (1) efforts for invoking a reduction in or resolution of an air-, land-, or water-related health concern; (2) the enactment of a strategy to address environmental health disparities; or (3) the application of an approach that enhanced community capacity, empowerment, leadership, or decision making in relation to environmental concerns.

\subsection{Measures}

A standardized form was used to extract relevant data that identified the policy, system, or environmental (PSE) change target [62,63]; capacity-building and community change strategies; and levels of community engagement. Additional abstraction measures (further detailed in Williamson et al., 2020) include author discipline, research design, study setting, and population demographics.

\subsubsection{Policy (P), System (S), or Environmental (E) Change Target}

Identified pollution concerns were categorized by one of the following: air pollution/air quality concerns; illegal dumping; hazardous waste inclusive of brownfields, superfund, chemical contaminants, soil contaminants, and fish contaminants; and waterquality concerns related to drinking water or groundwater. 


\subsubsection{Policy, System, or Environmental (PSE) Outcomes}

Environmental Outcomes

Environmental outcome measures were author-developed and identified how pollution concerns were addressed. Outcomes included: (1) reduction in an environmental pollutant; (2) reduction in or clean-up of environmental concern; (3) remediation of toxic waste; (4) increased regulation of air pollutants/particulate matter; and (5) reduction in indoor allergens (i.e., mold, infestation of rodents, mites, roaches, etc.).

Policy and System-Related Outcomes and Responses to Community Advocacy Efforts

The measurement of varying policy outcomes was author-created and generated from an iterative process during the screening phase of the scoping review. Outcomes included: (1) the enforcement of environmental laws, implemented or enhanced regulation, or review of conditional-use permits; (2) the mitigation of environmental concerns; (3) the prevention of industrial development of noxious facility; (4) the development of any legislation, policy, or law to address toxic emissions, exposures, or pollution concern; (5) the settlement or litigation related to the concern; (6) increased compliance or the mandatory payment of fines for violation; (7) the application of any of the aforementioned policy strategies that resulted in a failed policy outcome; and (8) engaging in discussion or having a meeting with a political figure to raise environmental concerns.

\subsubsection{Capacity-Building and Community Change Strategies}

\section{Strategies to Enhance Community Capacity}

Community capacity can be invoked in multiple ways to shape PSE change. Accordingly, six strategies (informed by Freudenberg's intervention strategies to increase community capacity) [60] were used to capture this variation and included: (1) authentic participation; (2) CBPR; (3) community organizing and social action; (4) empowerment approaches; (5) technical assistance; and (6) training and technology transfer.

\section{Direct Community Change Strategies}

Additional community strategies that did not fall within traditional academic-led research practices were author-identified [61] through an iterative process of reviewing EJ literature: civil disobedience, letter writing, litigation, media advocacy, partnership, coalition building, and policy advocacy (see Table 1 for measurement definitions and examples).

Table 1. Strategies to enhance community capacity.

\begin{tabular}{|c|c|}
\hline \multicolumn{2}{|c|}{ Strategies to Enhance Community Capacity Derived from Freudenberg [60] } \\
\hline $\begin{array}{l}\text { Authentic participation } \\
\text { processes }\end{array}$ & $\begin{array}{l}\text { A participation process that involves early engagement, the } \\
\text { provision of information and resources to ensure full } \\
\text { participation, and intentionality related to outcomes such that } \\
\text { final results are a reflection of that participation [60]. }\end{array}$ \\
\hline CBPR & $\begin{array}{l}\text { An intentional and meaningful practice of } \\
\text { community-centered research in which community members } \\
\text { are fully engaged in the research process by participating in } \\
\text { the selection of priority issues, design of the research study, } \\
\text { interpretation of findings, and presentation of results to } \\
\text { decision makers (i.e., policymakers) in efforts to reduce } \\
\text { environmental health inequities and promote healthier } \\
\text { public policies [60]. }\end{array}$ \\
\hline $\begin{array}{c}\text { Community organizing/social } \\
\text { action }\end{array}$ & $\begin{array}{c}\text { Community mobilization and organization to enable a } \\
\text { disadvantaged segment of the population to make demands } \\
\text { on the larger community for increased resources and more } \\
\text { equitable policies [60]. }\end{array}$ \\
\hline
\end{tabular}


Table 1. Cont.

\begin{tabular}{|c|c|}
\hline Empowerment approaches & $\begin{array}{l}\text { Process by which individuals, communities, and } \\
\text { organizations gain power and mastery over their lives in the } \\
\text { context of changing their social and political environment to } \\
\text { improve equity and quality of life [60]. }\end{array}$ \\
\hline Technical assistance & $\begin{array}{l}\text { Tailored support that enables community participants to gain } \\
\text { information or skills to solve problems or to participate more } \\
\text { effectively in decision-making processes [60]. }\end{array}$ \\
\hline $\begin{array}{c}\text { Training and technology } \\
\text { transfer }\end{array}$ & $\begin{array}{l}\text { Process by which community participants gain knowledge, } \\
\text { skills, competencies, or technologies that enable them to } \\
\text { participate in assessing and remediating environmental } \\
\text { hazards and participating in relevant policy deliberations [60]. }\end{array}$ \\
\hline \multicolumn{2}{|c|}{ Direct Community Change Strategies (Author-Created) [61] } \\
\hline Civil disobedience & $\begin{array}{l}\text { The refusal to comply with certain laws or to pay taxes and } \\
\text { fines, as a peaceful form of political protest, that often includes } \\
\text { nonviolent techniques such as boycotting, picketing [61]. }\end{array}$ \\
\hline Letter writing & $\begin{array}{c}\text { An organized effort to coordinate as many people as possible } \\
\text { to write to a decision maker (legislative or facility) asking } \\
\text { them to take a particular action [61]. }\end{array}$ \\
\hline Litigation & $\begin{array}{l}\text { The process of taking legal action to enforce or defend a legal } \\
\text { right [61]. }\end{array}$ \\
\hline Media advocacy & $\begin{array}{l}\text { Strategic use of traditional or social media outlets to } \\
\text { disseminate information and promote policy initiatives [61]. }\end{array}$ \\
\hline Photovoice & $\begin{array}{l}\text { A participatory method that has community participants use } \\
\text { photography, and stories about their photographs, to identify } \\
\text { and represent issues of importance to them [61]. }\end{array}$ \\
\hline Policy advocacy & $\begin{array}{l}\text { Analysis of the cause of the problem and development of } \\
\text { policy-based solutions to create sustainable change [61]. }\end{array}$ \\
\hline
\end{tabular}

\subsubsection{Community Engagement Continuum}

The community engagement continuum [64] was used to better understand the manner in which research investigators engage with and develop partnerships with an identified/targeted community. According to the Principles of Community Engagement, community engagement is defined as "the process of working collaboratively with and through groups of people affiliated by geographic proximity, special interest, or similar situations to address issues affecting the well-being of those people" [64]. This relationship often involves partnership and coalitions that help mobilize resources and influence systems, change relationships among partners, and serve as catalysts for changing policies, programs, and practices. The community engagement scale [64] used for this analysis consists of five increasing categories of involvement/communication and a sixth, author-created category:

(1) Outreach-limited community involvement in which communication is in one direction for the purpose of informing and only providing a community with information;

(2) Consult-more community involvement for the purpose of getting information from the community to obtain feedback and address particular questions;

(3) Involve- better community involvement in which communication flows in both directions and community members are involved in a participatory nature;

(4) Collaborate-increased community involvement such that communication is bidirectional, allowing for the development of partnership and community involvement on multiple aspects of a project from development to solution;

(5) Shared leadership - traditionally the most optimal form of engagement, in which leadership is bidirectional, strong community partnerships have formed, and final decision-making power is at the community level; and

(6) Community-led — community spearheads the project and vision, priorities are established by community residents, alongside the formation of strong partnerships that build on local strengths. 


\section{Results}

\subsection{Capacity-Building and Community Strategies to Address Pollution Concerns}

Capacity-building strategies described across included articles included: authentic involvement/participation of the community in planning and data collection $(96.4 \%, n=53$ Table 2); the implementation of empowerment approaches (77.6\%, $n=45)$; and community organizing/social action $(58.6 \%, n=34)$ that encouraged people to advocate for themselves and make demands for increased resources. Community-based participatory research (CBPR) was also a common strategy among half of included studies $(50 \%, n=29)$, with a demonstration of community participation at varying levels in the selection of priority issues, research design, interpretation of results, and dissemination efforts.

Table 2. Scoping Review Select Characteristics, $N=58$.

\begin{tabular}{|c|c|c|}
\hline \multicolumn{2}{|l|}{$N$} & $\%$ \\
\hline \multicolumn{3}{|c|}{ Capacity-Building and Community Change Strategies } \\
\hline \multicolumn{3}{|c|}{ Community capacity-building Strategies } \\
\hline Authentic participation processes & 53 & 96.4 \\
\hline Community-based participatory research CBPR) & 29 & 50.0 \\
\hline Community organizing/social action & 34 & 58.6 \\
\hline Empowerment approaches & 45 & 77.6 \\
\hline Technical assistance & 14 & 24.1 \\
\hline Training \& technology transfer & 12 & 20.7 \\
\hline \multicolumn{3}{|l|}{ Community Change Strategies } \\
\hline Citizen science & 13 & 22.4 \\
\hline Civil disobedience & 10 & 17.2 \\
\hline Letter writing & 6 & 10.3 \\
\hline Litigation & 18 & 31.0 \\
\hline Media advocacy & 19 & 32.8 \\
\hline Photovoice & 7 & 12.1 \\
\hline Policy advocacy & 14 & 24.1 \\
\hline \multicolumn{3}{|l|}{ Community Engagement Continuum } \\
\hline Outreach & 3 & 5.2 \\
\hline Consult & 5 & 8.6 \\
\hline Involve & 7 & 12.1 \\
\hline Collaborate & 15 & 25.9 \\
\hline Shared leadership & 16 & 27.6 \\
\hline Community-led & 11 & 19.0 \\
\hline Unable to determine level of engagement & 1 & 1.7 \\
\hline \multicolumn{3}{|l|}{ Observed environmental outcome } \\
\hline $\begin{array}{l}\text { Clean-up of pollution concern, reduced exposure, remediation of } \\
\text { toxic waste }\end{array}$ & 18 & 31.0 \\
\hline Increased regulation of $\mathrm{PM}_{2.5}$ & 0 & 0 \\
\hline $\begin{array}{c}\text { Other (i.e., roadway clearing, resident relocation, installation of } \\
\text { monitoring station) }\end{array}$ & 3 & 5.2 \\
\hline None reported & 35 & 60.3 \\
\hline
\end{tabular}


Table 2. Cont.

\begin{tabular}{|c|c|c|}
\hline$N$ & & $\%$ \\
\hline \multicolumn{3}{|c|}{ Policy-related outcomes as a result of advocacy efforts * } \\
\hline Discussions and meetings with political figures & 7 & 18.1 \\
\hline $\begin{array}{l}\text { Enforcement environmental law/regulation; review of } \\
\text { conditional-use permit }\end{array}$ & 11 & 18.9 \\
\hline $\begin{array}{l}\text { Increased compliance; mandatory payment of fines for pollution } \\
\text { and/or safety violations }\end{array}$ & 0 & 0 \\
\hline Legislative resolution to address toxic emissions & 13 & 22.4 \\
\hline Mitigation of concern & 17 & 29.3 \\
\hline Prevention of industrial development of noxious facility & 12 & 20.7 \\
\hline Other policy-related outcomes & 3 & 5.2 \\
\hline $\begin{array}{l}\text { Application of any aforementioned advocacy efforts with } \\
\text { unsuccessful policy-related outcomes }\end{array}$ & 10 & 17.2 \\
\hline $\begin{array}{l}\text { Mention of policy implications of findings but no direct } \\
\text { policy-related outcomes reported }\end{array}$ & 36 & 62.1 \\
\hline $\begin{array}{l}\text { No mention of policy implications and no policy-related } \\
\text { outcome reported }\end{array}$ & 14 & 24.1 \\
\hline
\end{tabular}

\subsection{Community Engagement and Relationships}

Most articles identified community engagement as being either shared leadership $(27.6 \%, n=16$; Table 1) with the formation of a strong partnership structure and the final decision making being made at the community level, or collaborative in nature $(25.9 \%$, $n=15$ ) with a bidirectional flow of communication from project development to solution. Less than one-quarter of included studies $(19 \%, n=11)$ were identified as being communityled and did not mention the participation of an academic partner guiding or engaged in addressing the issue of concern; even fewer studies engaged in community involvement as a primary interaction $(12.1 \%, n=7)$, consultation $(8.6 \%, n=5)$, and outreach-only relationships $(5.2 \%, n=1)$.

\subsection{Environmental and Policy-Related Outcome Resulting from Advocacy Efforts}

Contrary to the implementation of multiple strategies and advocacy work, many of the included studies did not result in any environmental change $(39.6 \%, n=23)$ or any type of direct policy change $(22.4 \%, n=13$; Table 2$)$; however, many authors did discuss the policy implications of their findings for future work $(62.1 \%, n=36)$. Approximately one-third of studies detailed having some sort of environmental impact $(36.2 \%, n=21)$ that resulted in the reduction in exposure to an environmental pollutant. Policy-related outcomes were detailed in about one-third of studies $(29 \%, n=17)$ in which mitigation of an environmental concern occurred by reducing the risk of the community to the exposure of the environmental pollutant (e.g., reducing emissions, making technical modifications to plant operations, or updating monitoring systems). Fewer examples were identified with studies that resulted in a legislative resolution to address environmental concerns $(22.4 \%, n=13)$ or the successful prevention of industrial development $(20.7 \%, n=12)$. Less than twenty percent of studies $(18.9 \%, n=11)$ detailed being able to encourage the enforcement of an existing environmental law, regulation, or review of a conditional permit. Very few studies $(5.2 \%, n=3)$ detailed having success with other policy-related outcomes related to the enactment of new policies or legislation (e.g., bus idling, stop signs, or new air regulations) and several studies referenced their failed advocacy efforts in making policy change $(n=17.2 \%, n=10)$. 


\section{Discussion}

Within the context of environmental justice literature, building capacity is fundamental for promoting solidarity in the development of local solutions to problems and enacting broader policy change. This systematic scoping review describes community-engaged partnerships and community-led advocacy efforts to address pollution-related EJ concerns and the environmental and policy-related changes that have resulted.

\subsection{The Community Engagement Continuum}

The community engagement continuum is applied to further understand the scope of research and the manner in which communities have been engaged with to address varying environmental concerns (see Table 3). This continuum is a reflection of the principles of community engagement [64], which stress the importance of collaboration, partnership, and coalition building to mobilize resources and influence systems change. This lens is applied because community involvement and collaboration are essential to the improvement of public health. It not only allows for the identification of local concerns but also fosters a sense of connectedness, builds community capacity, and lays the foundation for collective power to mobilize for environmental change. In the application of the traditional community engagement continuum, there are only five levels of categorization; however, through this review process, it became apparent that an additional level of higher engagement was being overlooked in the literature. Accordingly, a sixth level of engagement was authorcreated and identified as "community-led" to represent communities in which an academic entity was not identified as leading, guiding, or partnering to address environmental concerns. This higher level of engagement is also referred to in the literature as communityowned and -managed research (COMR) [56] and identifies communities that are utilizing their own lived experiences and expertise as well as collaborating with community-based organizations to shape an agenda and strategy to address environmental concerns.

Many of the included articles of this review were identified with being high on the scale of the community engagement continuum (see Appendix A Table A1). When communication was bi-directional and partnerships were formed on each aspect of the project from development to solution, collaborative engagement was realized [40,43,53,55,56,65-75]. Shared leadership was exemplified when community concerns were prioritized, diverse coalitions were formed, and final decision making was made at the community level [45-48,50,76-86]. The highest level of engagement, described as community-led, was demonstrated when communities set their own research questions, selected partners for collaboration, and managed the implementation of solutions and dissemination of findings [87-99]. Fewer studies were categorized as being low-engagement, in which: information flowed in one direction from researchers to community (outreach) [100]; information fed to the community and was also extracted from the community (consult) [52,101-104]; or communication was bidirectional, cooperative, and involved community participation (involve) [44,51,105-110].

\subsection{Relationship between Community Engagement and PSE Change}

When making comparisons between the high and low levels of engagement, there appeared to be a trend with respect to the types of capacity-building strategies that were being utilized and the degree of success in making impactful community/policy change. Articles with higher engagement were more often involved in strategies related to empowerment, leadership, the identification of resources, and letter-writing activities. Higher-engagement articles also had greater discussion of policy-related outcomes with respect to the introduction of legislative resolutions to address toxic emissions and successful settlement or litigation related to environmental concerns. Consequently, it may be that these higherengagement articles observed appreciable successes because of the greater emphasis on community priorities and alignment with community values, and were intentional in their sustainability efforts, which in turn created enhanced opportunities for realized community change. 
Table 3. Community Engagement Continuum Study Examples.

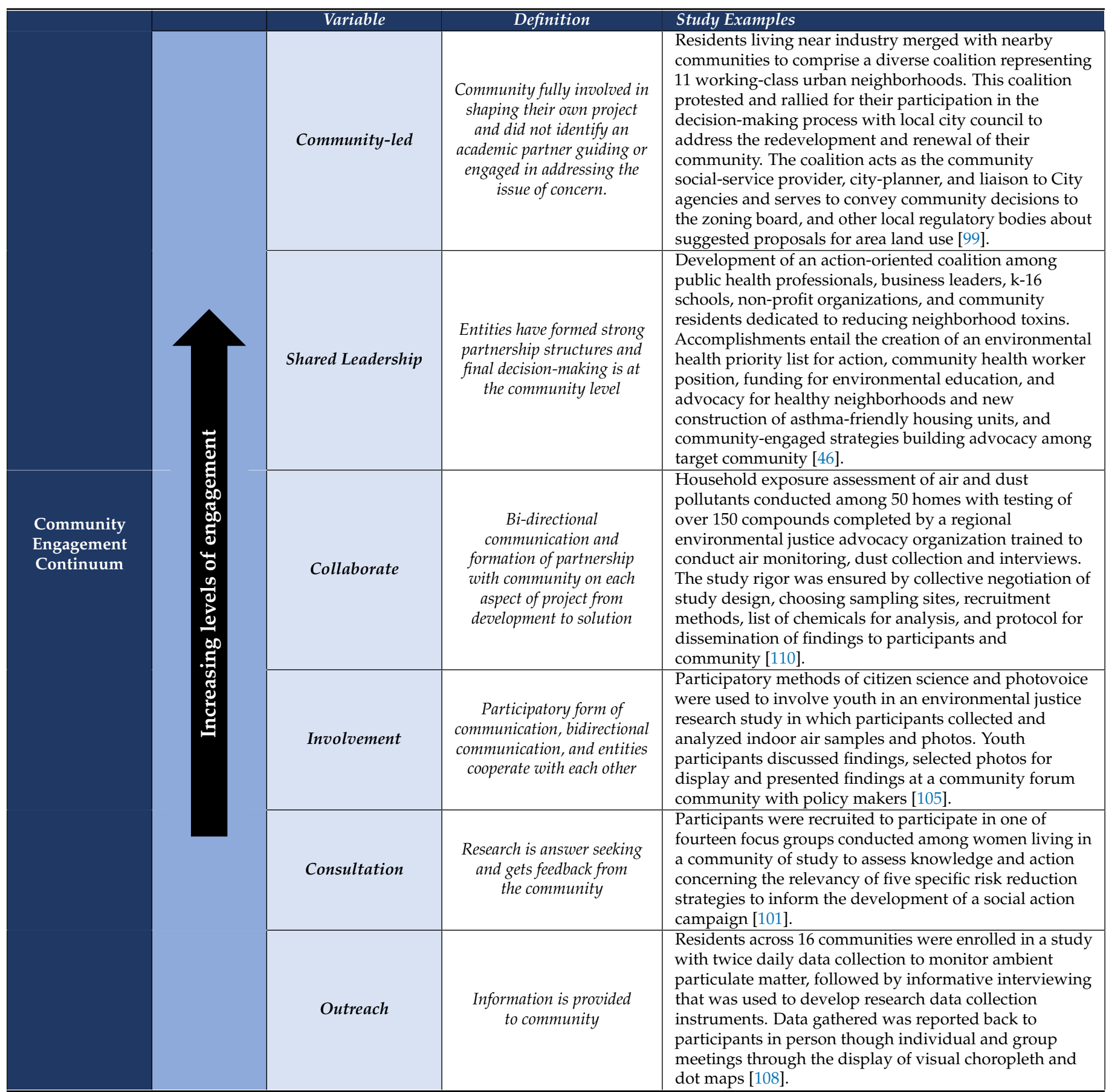

These findings further emphasize that the ways in which researchers are engaging with communities may influence the impact that is made in driving meaningful and sustainable environmental, policy, and systems change. Community engagement is not just a step and checkbox in the research process. Deliberately making communities a part of the entire process from start to solution not only allows for greater connection but also for the identification of practices that are grounded, relevant, and potentially more sustainable in the long term. This intentional and meaningful practice of community-centered research is often referenced as CBPR and is a model strategy for engaging community in addressing local environmental concerns/inequities [40-57]. However, while this CBPR term was cited among half of the articles in this review, the fidelity of this practice was not always adhered to. On the community engagement continuum, CBPR would traditionally fall 
into the "collaborate" stage [109], in which community would be partnered with and fully involved in all stages from development to solution; however, about $25 \%$ of these articles were actually conducting research at a much lower level of engagement. Among these, the understanding of the CBPR orientation varied greatly, where some implemented participant inquiry methods such as photovoice [52,105], citizen science [51,105], or performance theater [104], and others defined CBPR practice within the context of focus groups and group discussions [44,100-102]. To this extent, the manner in which CBPR is practiced can have varying impacts on the community with respect to moving the needle towards environmental justice. Unfortunately, CBPR research practices "have the ability to build capacity, but it is not always applied in a way that produces data to initiate compliance with civil rights, environmental, planning, and public health regulations (p.287, [109])".

While CBPR represents the gold standard for engagement, it is only one equity-based approach, as the process of capacity building does not have to be constrained within an academic-partnership model. Capacity building can be represented across a myriad of diverse approaches employed at the community level to accomplish goals. Apart from one instance in which community-led research borrowed from the CBPR orientation and formed a resident-nonprofit organization partnership [93], the strategies employed to enhance capacity to address environmental justice concerns also included civil disobedience (peaceful political protests), citizen science, community organizing/mobilization, letter writing, and the application of technical assistance. Half of these community-led environmental justice studies were able to achieve environmental change with respect to the reduction in exposures to pollutants, prevention of industry development, and successful settlement/litigation related to their concerns. These findings can lend additional credibility to the power in not only engaging community but allowing community to fully manage the agenda in addressing local environmental concerns and inequities.

\subsection{Limitations}

This review was limited to peer-reviewed literature published in English and conducted in the United States, as reported in the peer-reviewed literature. Hence, the ability to compare and/or generalize these findings to what would be present in grey literature, research organization publications, and other geographic contexts is limited. Most articles included in this review are written from an academic lens in which varying methodologies and research designs are used; thus, making comparisons across studies is challenging to determine which strategies are most impactful in addressing environmental inequities and producing positive PSE community changes. This limitation continues to be a challenge within the scope of environmental justice work [110]. Further, while legislative, policy, and environmental change are optimal research outcomes, studying these changes within the scope of a cross-sectional review of this type are limiting given the lack of longitudinal observation and reporting. Consequently, there is great value in continuing to analyze the breadth of research conducted in this field, the identification of effective practices, and resulting PSE outcomes. Future efforts of this nature would not only add to the body of science [111], but results would be instrumental in advancing EJ and community-centered public health-oriented EJ efforts.

\section{Conclusions}

The field of EJ is grounded in community advocacy and has a history of bringing together varying stakeholders to create strategies to improve health outcomes. Many academics have acknowledged the value of forming community alliances and have discussed the necessity of building community capacity to address local environmental concerns and inequities [40-57]. While this scoping review has detailed a multitude of strategies and advocacy efforts that have involved or engaged communities in varying fashions, broadly these efforts have not made substantial progress in stimulating changes at the environmental or policy level. In this regard, it is important to stress the intentionality and reflexivity that is required with environmental justice efforts. If the research that is 
being conducted is not driving the changes that are needed, then it is worth evaluating the strategies that are being used and not used, and assessing if the research is valuing and impacting the lives of community in the way that is most beneficial for them.

This work is the first body of literature to synthesize: a myriad of community-led and community-academic partnership strategies to address EJ issues; identify trends of EJ-related policy and environmental structural change strategies and outcomes; and utilize the community engagement continuum as frameworks for understanding EJ-related work. It is the intention that the findings of this scoping review can aid in improving praxis, give greater insight for making transformative change, and assist in the development of fruitful partnerships to achieve environmental justice.

Funding: This research was supported by funding from Robert Wood Johnson Foundation, Health Policy Research Scholars Program Cohort 1; Emory University Award I.D. 73920; Grant period 1 September 2016-31 August 2020.

Institutional Review Board Statement: Not Applicable.

Informed Consent Statement: Not Applicable.

Data Availability Statement: The data presented in this study are available in the tables and figures and additional data can be obtained from the primary scoping review article at https: / /www.mdpi. com/1660-4601/17/11/3765/htm accessed on 15 January 2022.

Acknowledgments: Thank you Emma Yu, Candis Hunter, John Kaufman, Bridget Harding, Shade Owolabi, and Carlie Rhiness for your dedication to this project and your time commitment to article screening and data abstraction!

Conflicts of Interest: The author declares no conflict of interest. The funders had no role in the design of the study; in the collection, analyses, or interpretation of data; in the writing of the manuscript, or in the decision to publish the results. 


\section{Appendix A}
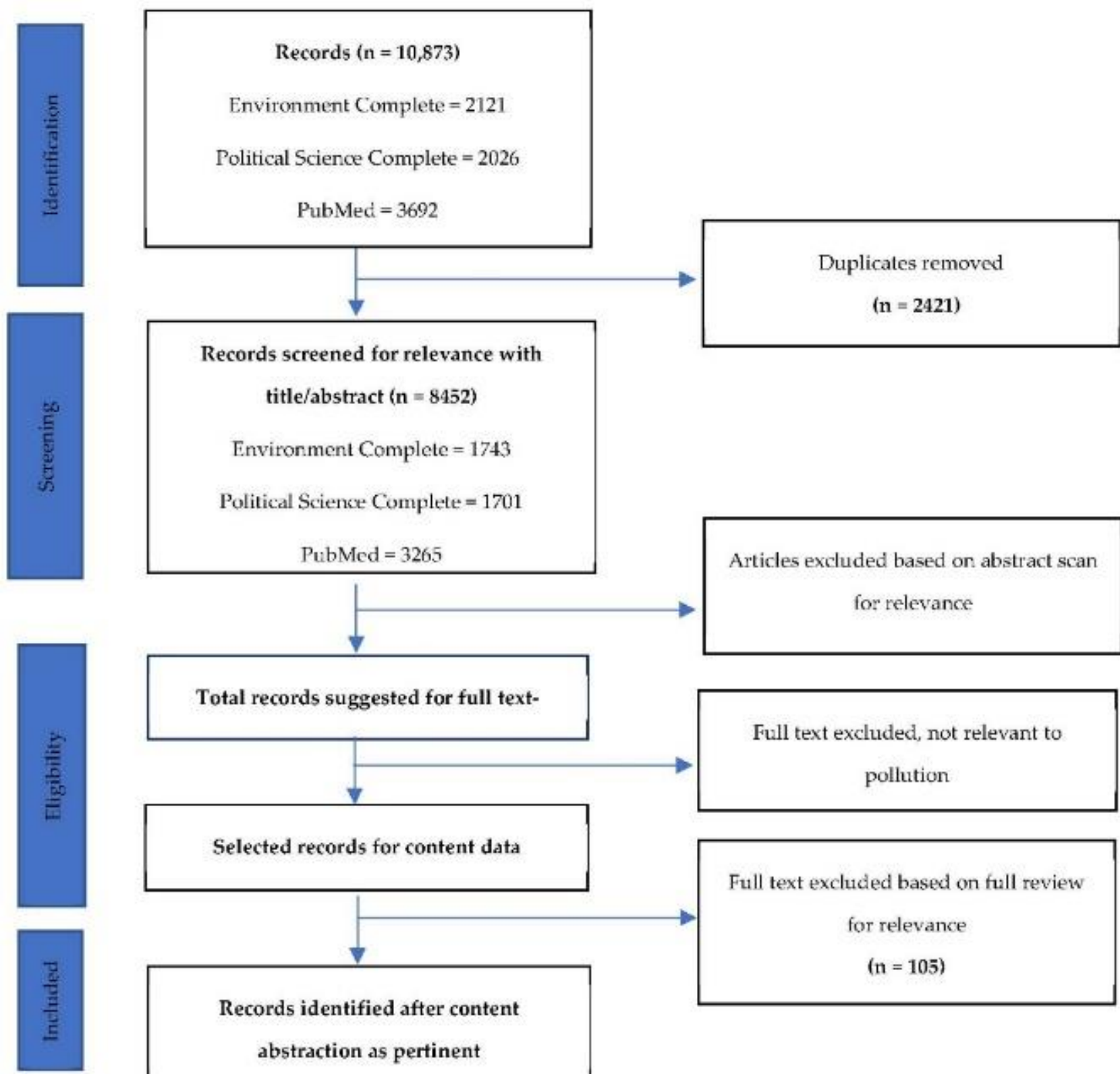

abstraction as pertinent

Figure A1. Cont. 

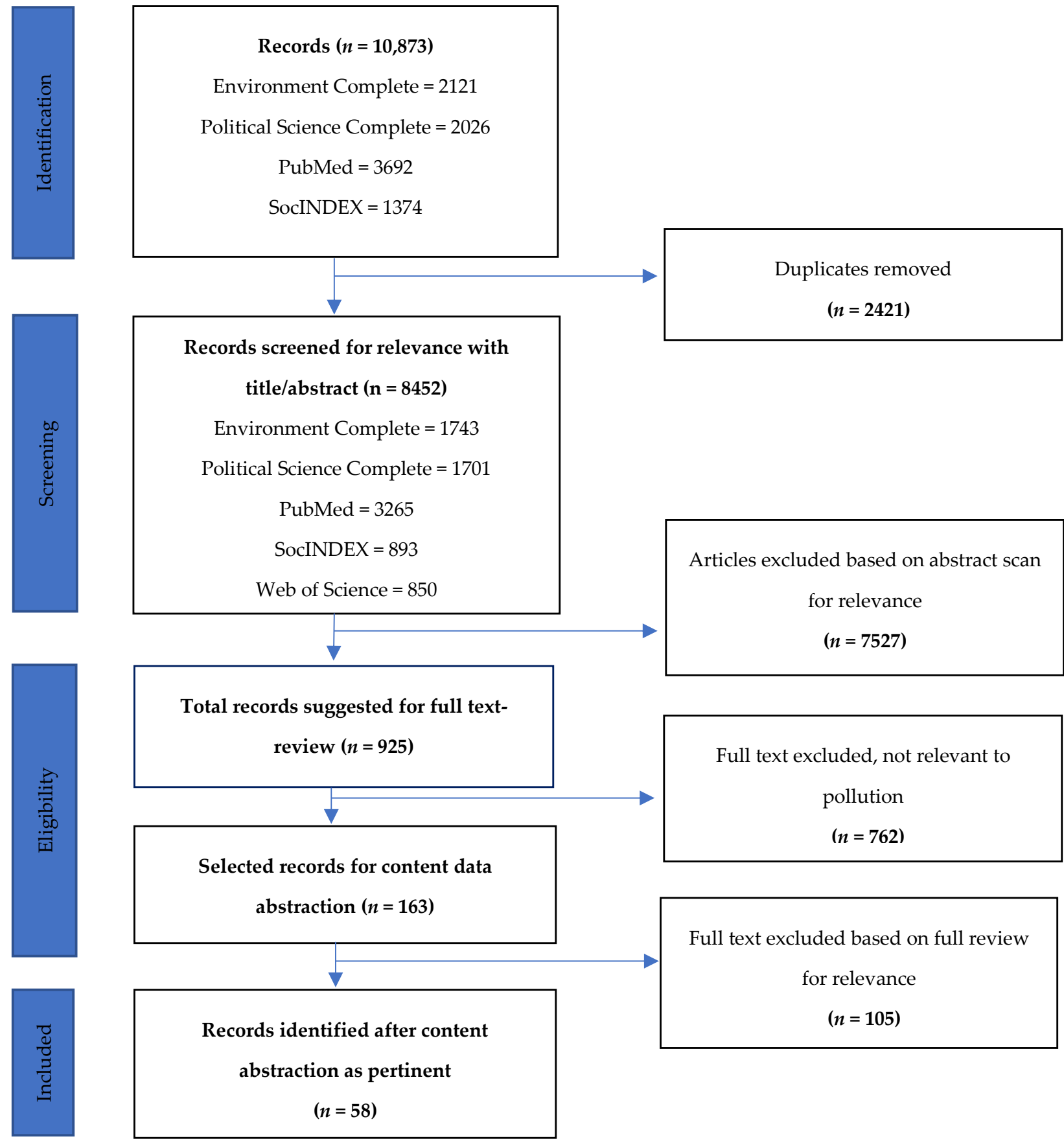

abstraction as pertinent

$(n=58)$

Figure A1. Prisma Flow Diagram. 
Table A1. Community Engagement by Study.

\begin{tabular}{|c|c|c|c|c|c|c|c|c|}
\hline \multirow{2}{*}{ Included Articles } & & \multicolumn{7}{|c|}{ Community Engagement Continuum: Levels of Community Engagement } \\
\hline & & Outreach & Consultation & Involvement & Collaborate & $\begin{array}{c}\text { Shared } \\
\text { Leadership }\end{array}$ & $\begin{array}{c}\text { Community- } \\
\text { Led }\end{array}$ & $\begin{array}{l}\text { Unable to } \\
\text { Determine }\end{array}$ \\
\hline $\mathbf{N}(\%)$ & $\begin{array}{c}\text { Publication } \\
\text { Year }\end{array}$ & $\begin{array}{c}3 \\
(1.7 \%)\end{array}$ & $\begin{array}{c}5 \\
(8.6 \%)\end{array}$ & $\begin{array}{c}7 \\
(10.3 \%)\end{array}$ & $\begin{array}{c}15 \\
(27.6 \%)\end{array}$ & $\begin{array}{c}16 \\
(27.6 \%)\end{array}$ & $\begin{array}{c}11 \\
(22.4 \%)\end{array}$ & $\begin{array}{c}1 \\
(1.7 \%)\end{array}$ \\
\hline $\begin{array}{l}\text { Bullard, R. D. and B. H. Wright. The quest for } \\
\text { environmental equity-Mobilizing the } \\
\text { African-American community for social-change. } \\
\text { Soc \& Nat Resources 3(4): 301-311. }\end{array}$ & 1990 & & & & & & $X$ & \\
\hline $\begin{array}{l}\text { Čapek, S. M. Environmental Justice Regulation } \\
\text { and the local-community. Int Journal of Health } \\
\text { Services 22(4): 729-746. }\end{array}$ & 1992 & & & & & & $X$ & \\
\hline $\begin{array}{l}\text { Jacobs, J. A Community Organizing Case Study: } \\
\text { An Analysis of Cap-It's Strategy to Prevent the } \\
\text { Location of a Toxic Waste Incinerator in Their } \\
\text { Community. Int Q Community Health Educ 13(3): } \\
\text { 253-263. }\end{array}$ & 1992 & & & & & & $X$ & \\
\hline $\begin{array}{l}\text { Čapek, S. M. The Environmental Justice Frame: A } \\
\text { Conceptual Discussion and an Application. Social } \\
\text { Problems 40(1): 5-24. }\end{array}$ & 1993 & & & & & & $X$ & \\
\hline $\begin{array}{l}\text { Brown, P. and S. Masterson-Allen. The toxic-waste } \\
\text { movement-A new type of activism. Society \& } \\
\text { Natural Resources 7(3): } 269-287 .\end{array}$ & 1994 & & & & & & $X$ & \\
\hline $\begin{array}{l}\text { Allen, B. L. Saving St. Gabriel: The Emergence of } \\
\text { a new African-American town Contemporary } \\
\text { Justice Review 4(2): } 145 .\end{array}$ & 2001 & & & & $X$ & & & \\
\hline $\begin{array}{l}\text { Corburn, J. Combining community-based research } \\
\text { and local knowledge to confront asthma and } \\
\text { subsistence-fishing hazards in } \\
\text { Greenpoint/Williamsburg, Brooklyn, NY. Environ } \\
\text { Health Perspect. S110-2: 241-8. }\end{array}$ & 2002 & & & & & & $X$ & \\
\hline
\end{tabular}


Table A1. Cont.

\begin{tabular}{|c|c|c|c|c|c|c|c|c|}
\hline & & & Commun & Engagement $\mathrm{C}$ & tinuum: Leve & Community & gagement & \\
\hline Included Articles & & Outreach & Consultation & Involvement & Collaborate & $\begin{array}{l}\text { Shared } \\
\text { Leadership }\end{array}$ & $\begin{array}{l}\text { Community- } \\
\text { Led }\end{array}$ & $\begin{array}{l}\text { Unable to } \\
\text { Determine }\end{array}$ \\
\hline $\mathbf{N}(\%)$ & $\begin{array}{l}\text { Publication } \\
\text { Year }\end{array}$ & $\begin{array}{c}3 \\
(1.7 \%)\end{array}$ & $\begin{array}{c}5 \\
(8.6 \%)\end{array}$ & $\begin{array}{c}7 \\
(10.3 \%)\end{array}$ & $\begin{array}{c}15 \\
(27.6 \%)\end{array}$ & $\begin{array}{c}16 \\
(27.6 \%)\end{array}$ & $\begin{array}{c}11 \\
(22.4 \%)\end{array}$ & $\begin{array}{c}1 \\
(1.7 \%)\end{array}$ \\
\hline $\begin{array}{l}\text { Green, L., et al. "Hey, mom, thanks!": Use of focus } \\
\text { groups in the development of place-specific } \\
\text { materials for a community environmental action } \\
\text { campaign. Environ Health Perspect } 110 \text { Suppl 2: } \\
\text { 265-269. }\end{array}$ & 2002 & & $X$ & & & & & \\
\hline $\begin{array}{l}\text { Loh, P., et al. From Asthma to AirBeat. Environ } \\
\text { Health Perspect S110: } 297 .\end{array}$ & 2002 & & & & & $X$ & & \\
\hline $\begin{array}{l}\text { Brown, P., et al. The health politics of asthma: } \\
\text { environmental justice and collective illness } \\
\text { experience in the United States. Soc Sci Med 57(3): } \\
453-464 .\end{array}$ & 2003 & & & & $x$ & & & \\
\hline $\begin{array}{c}\text { Johnson, G. S. Grassroots Activism in Louisiana. } \\
\text { Humanity \& Soc 29(3/4): 285-304. }\end{array}$ & 2005 & & & & & $X$ & & \\
\hline $\begin{array}{l}\text { Blodgett, A. D. An Analysis of Pollution and } \\
\text { Community Advocacy in 'Cancer Alley': Setting } \\
\text { an Example for the Environmental Justice } \\
\text { Movement in St James Parish, Louisiana. Local } \\
\text { Environment 11(6): 647-661. }\end{array}$ & 2006 & $x$ & & & & & & \\
\hline $\begin{array}{l}\text { Grineski, S. E. Local Struggles for Environmental } \\
\text { Justice: Activating Knowledge for Change. } \\
\text { Journal of Poverty 10(3): 25-49. }\end{array}$ & 2006 & & & & & $X$ & & \\
\hline $\begin{array}{l}\text { Tajik, M. and M. Minkler. Environmental justice } \\
\text { research and action: a case study in political } \\
\text { economy and community-academic collaboration. } \\
\text { Int Q Community Health Educ 26(3): 213-231. }\end{array}$ & 2006 & & & & $x$ & & & \\
\hline $\begin{array}{l}\text { Higman, K., et al. Using the PACE EH model to } \\
\text { mobilize communities to address local } \\
\text { environmental health issues-A case study in } \\
\text { Island County, Washington. J Environ Health } \\
\text { 70(1): 37-41. }\end{array}$ & 2007 & $x$ & & & & & & \\
\hline
\end{tabular}


Table A1. Cont.

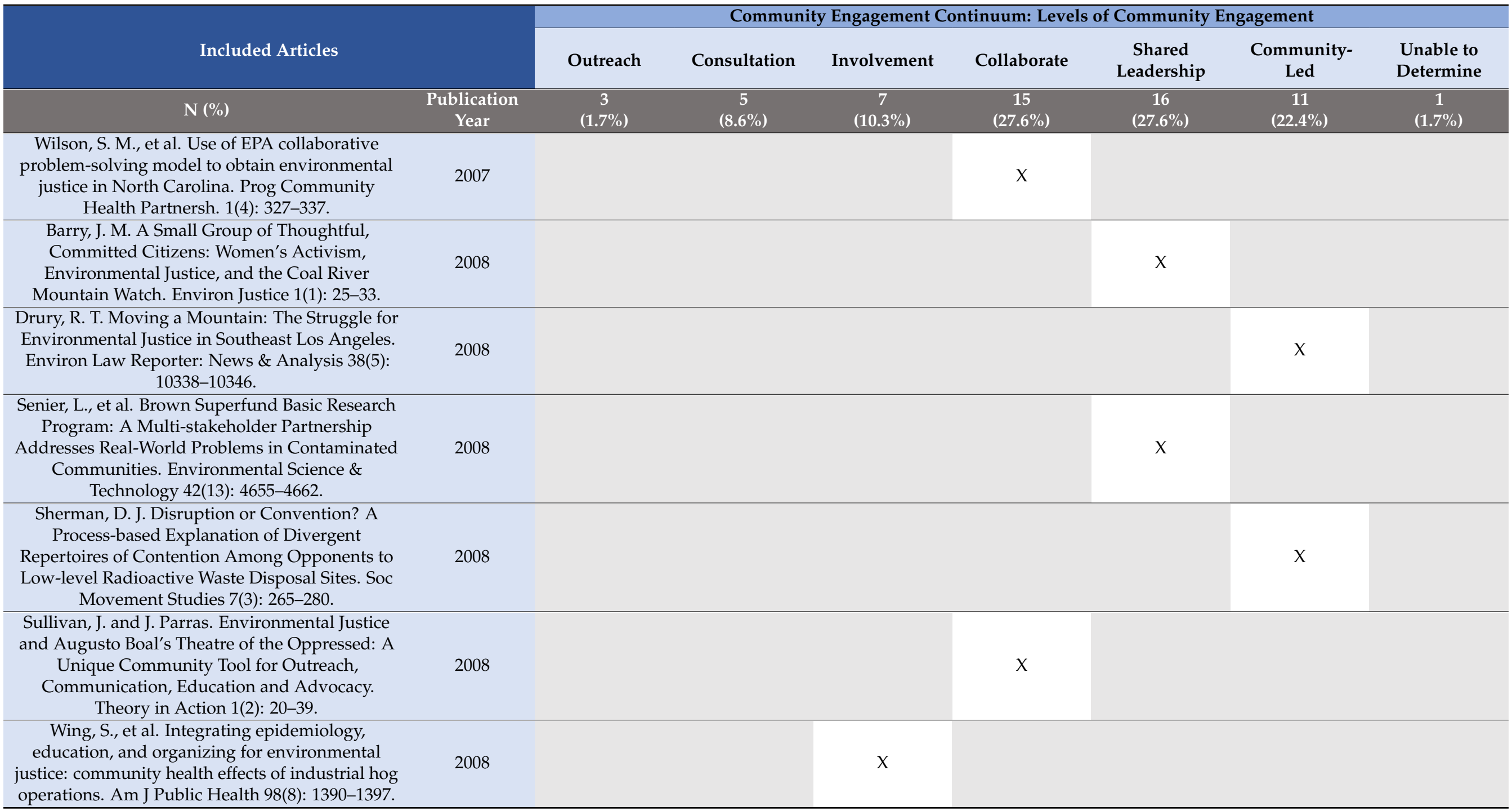


Table A1. Cont.

\begin{tabular}{|c|c|c|c|c|c|c|c|c|}
\hline & & & Commun & Engagement C & tinuum: Leve & Community & ragement & \\
\hline Included Articles & & Outreach & Consultation & Involvement & Collaborate & $\begin{array}{c}\text { Shared } \\
\text { Leadership }\end{array}$ & $\begin{array}{l}\text { Community- } \\
\text { Led }\end{array}$ & $\begin{array}{l}\text { Unable to } \\
\text { Determine }\end{array}$ \\
\hline $\mathbf{N}(\%)$ & $\begin{array}{l}\text { Publication } \\
\text { Year }\end{array}$ & $\begin{array}{c}3 \\
(1.7 \%)\end{array}$ & $\begin{array}{c}5 \\
(8.6 \%)\end{array}$ & $\begin{array}{c}7 \\
(10.3 \%)\end{array}$ & $\begin{array}{c}15 \\
(27.6 \%)\end{array}$ & $\begin{array}{c}16 \\
(27.6 \%)\end{array}$ & $\begin{array}{c}11 \\
(22.4 \%)\end{array}$ & $\begin{array}{c}1 \\
(1.7 \%)\end{array}$ \\
\hline $\begin{array}{l}\text { Schelly, D. and P. B. Stretesky. An Analysis of the } \\
\text { Path of Least Resistance Argument in Three } \\
\text { Environmental Justice Success Cases. Society \& } \\
\text { Natural Resources 22(4): 369-380. }\end{array}$ & 2009 & & & & & & $x$ & \\
\hline $\begin{array}{l}\text { Wier, M., et al. Health, traffic, and environmental } \\
\text { justice: collaborative research and community } \\
\text { action in San Francisco, California. Am J Public } \\
\text { Health } 99 \text { Suppl 3: S499-504. }\end{array}$ & 2009 & & & & $x$ & & & \\
\hline $\begin{array}{l}\text { Williams, E. M., et al. Behind the fence forum } \\
\text { theater: an arts performance partnership to } \\
\text { address lupus and environmental justice. New } \\
\text { Solut. 19(4): 467-479. }\end{array}$ & 2009 & & & & $X$ & & & \\
\hline $\begin{array}{c}\text { Emmett, E. A. and C. Desai. Community First } \\
\text { Communication: Reversing Information } \\
\text { Disparities to Achieve Environmental Justice. } \\
\text { Environ Justice 3(3): 79-84. }\end{array}$ & 2010 & & & & & $x$ & & \\
\hline $\begin{array}{l}\text { Kegler, M. C., et al. Primary Prevention of Lead } \\
\text { Poisoning in Rural Native American Children: } \\
\text { Behavioral Outcomes from a Community-Based } \\
\text { Intervention in a Former Mining Region. Family \& } \\
\text { Community Health 33(1): 32-43. }\end{array}$ & 2010 & & & & $X$ & & & \\
\hline $\begin{array}{l}\text { Minkler, M. Linking Science and Policy Through } \\
\text { Community-Based Participatory Research to } \\
\text { Study and Address Health Disparities. Am J of } \\
\text { Public Health 100: S81-7. }\end{array}$ & 2010 & & & & & $x$ & & \\
\hline $\begin{array}{l}\text { Minkler, M., et al. Sí se puede: using participatory } \\
\text { research to promote environmental justice in a } \\
\text { Latino community in San Diego, California. J } \\
\text { Urban Health 87(5): 796-812. }\end{array}$ & 2010 & & & & & $X$ & & \\
\hline
\end{tabular}


Table A1. Cont.

\begin{tabular}{|c|c|c|c|c|c|c|c|c|}
\hline & & & Commun & Engagement & tinuum: Leve & Community & gagement & \\
\hline Included Articles & & Outreach & Consultation & Involvement & Collaborate & $\begin{array}{c}\text { Shared } \\
\text { Leadership }\end{array}$ & $\begin{array}{l}\text { Community- } \\
\text { Led }\end{array}$ & $\begin{array}{l}\text { Unable to } \\
\text { Determine }\end{array}$ \\
\hline $\mathbf{N}(\%)$ & $\begin{array}{c}\text { Publication } \\
\text { Year }\end{array}$ & $\begin{array}{c}3 \\
(1.7 \%)\end{array}$ & $\begin{array}{c}5 \\
(8.6 \%)\end{array}$ & $\begin{array}{c}7 \\
(10.3 \%)\end{array}$ & $\begin{array}{c}15 \\
(27.6 \%)\end{array}$ & $\begin{array}{c}16 \\
(27.6 \%)\end{array}$ & $\begin{array}{c}11 \\
(22.4 \%)\end{array}$ & $\begin{array}{c}1 \\
(1.7 \%)\end{array}$ \\
\hline $\begin{array}{l}\text { Parker, N. E. A., et al. (2010). Community } \\
\text { organizing network for environmental health: } \\
\text { using a community health development approach } \\
\text { to increase community capacity around reduction } \\
\text { of environmental triggers. J Prim Prev 31(1-2): } \\
41-58 \text {. }\end{array}$ & 2010 & & & & $\mathrm{x}$ & & & \\
\hline $\begin{array}{l}\text { Sicotte, D. (2010). Don't Waste Us: Environmental } \\
\text { Justice through Community Participation in } \\
\text { Urban Planning. Enviro Justice (19394071) 3(1): } \\
7-11 .\end{array}$ & 2010 & & & & & & $\mathrm{X}$ & \\
\hline $\begin{array}{l}\text { Gonzalez, P. A., et al. (2011). Community-Based } \\
\text { Participatory Research and Policy Advocacy to } \\
\text { Reduce Diesel Exposure in West Oakland, } \\
\text { California. Am J of Public Health 101: S166-S175. }\end{array}$ & 2011 & & & & & $x$ & & \\
\hline $\begin{array}{c}\text { Kreger, M., et al. (2011). Creating an } \\
\text { environmental justice framework for policy } \\
\text { change in childhood asthma: A grassroots to } \\
\text { treetops approach. Am J Public Health } 101 \text { Suppl } \\
\text { 1: S208-S216. }\end{array}$ & 2011 & & & & $\mathrm{X}$ & & & \\
\hline $\begin{array}{l}\text { Stedman-Smith, M., et al. (2012). Photovoice in } \\
\text { the Red River Basin of the north: a systematic } \\
\text { evaluation of a community-academic partnership. } \\
\text { Health Promot Pract 13(5): 599-607. }\end{array}$ & 2012 & & $\mathrm{X}$ & & & & & \\
\hline
\end{tabular}


Table A1. Cont.

\begin{tabular}{|c|c|c|c|c|c|c|c|c|}
\hline & & & Commun & Engagement & tinuum: Leve & Community & gagement & \\
\hline Included Articles & & Outreach & Consultation & Involvement & Collaborate & $\begin{array}{c}\text { Shared } \\
\text { Leadership }\end{array}$ & $\begin{array}{l}\text { Community- } \\
\text { Led }\end{array}$ & $\begin{array}{l}\text { Unable to } \\
\text { Determine }\end{array}$ \\
\hline $\mathbf{N}(\%)$ & $\begin{array}{c}\text { Publication } \\
\text { Year }\end{array}$ & $\begin{array}{c}3 \\
(1.7 \%)\end{array}$ & $\begin{array}{c}5 \\
(8.6 \%)\end{array}$ & $\begin{array}{c}7 \\
(10.3 \%)\end{array}$ & $\begin{array}{c}15 \\
(27.6 \%)\end{array}$ & $\begin{array}{c}16 \\
(27.6 \%)\end{array}$ & $\begin{array}{c}11 \\
(22.4 \%)\end{array}$ & $\begin{array}{c}1 \\
(1.7 \%)\end{array}$ \\
\hline $\begin{array}{l}\text { Dressel, A., et al. The Westlawn Partnership for a } \\
\text { Healthier Environment: Promoting } \\
\text { Environmental Justice and Building Community } \\
\text { Capacity. Environmental Justice (19394071) 6(4): } \\
\text { 127-132. }\end{array}$ & 2013 & & & & & $x$ & & \\
\hline $\begin{array}{l}\text { Garcia, A. P., et al. THE (Trade, Health, } \\
\text { Environment) Impact Project: A } \\
\text { Community-Based Participatory Research } \\
\text { Environmental Justice Case Study. Environ Justice } \\
6(1): 17-26 .\end{array}$ & 2013 & & & & & $x$ & & \\
\hline $\begin{array}{l}\text { Balazs, C. L. and R. Morello-Frosch. The Three Rs: } \\
\text { How Community-Based Participatory Research } \\
\text { Strengthens the Rigor, Relevance, and Reach of } \\
\text { Science. Environmental Justice (19394071) 6(1): } \\
\text { 9-16. }\end{array}$ & 2013 & & & $x$ & & & & \\
\hline $\begin{array}{l}\text { Miller, P. K., et al. Community-based participatory } \\
\text { research projects and policy engagement to } \\
\text { protect environmental health on St Lawrence } \\
\text { Island, Alaska. Int J Circumpolar Health } 72 .\end{array}$ & 2013 & & & & $x$ & & & \\
\hline $\begin{array}{l}\text { Sadd, J., et al. The Truth, the Whole Truth, and } \\
\text { Nothing but the Ground-Truth: Methods to } \\
\text { Advance Environmental Justice and } \\
\text { Researcher-Community Partnerships. Health } \\
\text { Educ Behav 41(3): 281-290. }\end{array}$ & 2014 & & & $x$ & & & & \\
\hline $\begin{array}{l}\text { Bell, S. E. Bridging Activism and the Academy: } \\
\text { Exposing Environmental Injustices Through the } \\
\text { Feminist Ethnographic Method of Photovoice. } \\
\text { Human Ecol Rev 21(1): } 27-58 .\end{array}$ & 2015 & & & & $\mathrm{x}$ & & & \\
\hline $\begin{array}{l}\text { Hines, R. I. The Price of Pollution: The Struggle } \\
\text { for Environmental Justice in Mossville, Louisiana. } \\
\text { Western Journal of Black Studies 39(3): 198-208. }\end{array}$ & 2015 & & & & & & $x$ & \\
\hline
\end{tabular}


Table A1. Cont.

\begin{tabular}{|c|c|c|c|c|c|c|c|c|}
\hline & & & Commun & Engagement $\mathrm{C}$ & tinuum: Leve & Community & gagement & \\
\hline Included Articles & & Outreach & Consultation & Involvement & Collaborate & $\begin{array}{l}\text { Shared } \\
\text { Leadership }\end{array}$ & $\begin{array}{l}\text { Community- } \\
\text { Led }\end{array}$ & $\begin{array}{l}\text { Unable to } \\
\text { Determine }\end{array}$ \\
\hline $\mathbf{N}(\%)$ & $\begin{array}{l}\text { Publication } \\
\text { Year }\end{array}$ & $\begin{array}{c}3 \\
(1.7 \%)\end{array}$ & $\begin{array}{c}5 \\
(8.6 \%)\end{array}$ & $\begin{array}{c}7 \\
(10.3 \%)\end{array}$ & $\begin{array}{c}15 \\
(27.6 \%)\end{array}$ & $\begin{array}{c}16 \\
(27.6 \%)\end{array}$ & $\begin{array}{c}11 \\
(22.4 \%)\end{array}$ & $\begin{array}{c}1 \\
(1.7 \%)\end{array}$ \\
\hline $\begin{array}{c}\text { Jiao, Y., et al. Application of Citizen Science Risk } \\
\text { Communication Tools in a Vulnerable Urban } \\
\text { Community. Int J Environ Res Public Health 13(1): } \\
\text { ijerph13010011. }\end{array}$ & 2015 & & & $x$ & & & & \\
\hline $\begin{array}{l}\text { Rohlman, D., et al. A Community-Based } \\
\text { Approach to Developing a Mobile Device for } \\
\text { Measuring Ambient Air Exposure, Location, and } \\
\text { Respiratory Health. Environ Justice 8(4): 126-134. }\end{array}$ & 2015 & & $X$ & & & & & \\
\hline $\begin{array}{l}\text { Schwartz, N. A., et al. Where they (live, work and) } \\
\text { spray: pesticide exposure, childhood asthma and } \\
\text { environmental justice among Mexican-American } \\
\text { farmworkers. Health Place 32: 83-92. }\end{array}$ & 2015 & & & & & $x$ & & \\
\hline $\begin{array}{l}\text { White, B. M. and E. S. Hall. Perceptions of } \\
\text { environmental health risks among residents in the } \\
\text { Toxic Doughnut: opportunities for risk screening } \\
\text { and community mobilization. BMC Public Health } \\
\text { 15: } 1230 .\end{array}$ & 2015 & $X$ & & & & & & \\
\hline $\begin{array}{l}\text { Cohen, A. K., et al. Surveying for Environmental } \\
\text { Health Justice: Community Organizing } \\
\text { Applications of Community-Based Participatory } \\
\text { Research. Environ Justice 9(5): 129-136. }\end{array}$ & 2016 & & & $X$ & & & & \\
\hline $\begin{array}{c}\text { Kaup, B. Z. and D. Casey. Coalition of injustice? } \\
\text { Bodies, business, and the biosphere in struggles } \\
\text { against unwanted land uses. Environmental } \\
\text { Politics 25(3): 494-512. }\end{array}$ & 2016 & & & & & $x$ & & \\
\hline $\begin{array}{l}\text { Robinson, E. E. Sharing Stories. Humanity \& } \\
\text { Society 40(4): 442-461. }\end{array}$ & 2016 & & & & & $X$ & & \\
\hline $\begin{array}{l}\text { Spencer-Hwang, R., et al. Strategic Partnerships } \\
\text { for Change in an Environmental Justice } \\
\text { Community: The ENRRICH Study. Prog } \\
\text { Community Health Partnersh. 10(4): 541-550. }\end{array}$ & 2016 & & $\mathrm{x}$ & & & & & \\
\hline
\end{tabular}


Table A1. Cont.

\begin{tabular}{|c|c|c|c|c|c|c|c|c|}
\hline & & & Commun & Engagement $C$ & tinuum: Leve & Community & ragement & \\
\hline Included Articles & & Outreach & Consultation & Involvement & Collaborate & $\begin{array}{c}\text { Shared } \\
\text { Leadership }\end{array}$ & $\begin{array}{c}\text { Community- } \\
\text { Led }\end{array}$ & $\begin{array}{l}\text { Unable to } \\
\text { Determine }\end{array}$ \\
\hline $\mathbf{N}(\%)$ & $\begin{array}{c}\text { Publication } \\
\text { Year }\end{array}$ & $\begin{array}{c}3 \\
(1.7 \%)\end{array}$ & $\begin{array}{c}5 \\
(8.6 \%)\end{array}$ & $\begin{array}{c}7 \\
(10.3 \%)\end{array}$ & $\begin{array}{c}15 \\
(27.6 \%)\end{array}$ & $\begin{array}{c}16 \\
(27.6 \%)\end{array}$ & $\begin{array}{c}11 \\
(22.4 \%)\end{array}$ & $\begin{array}{c}1 \\
(1.7 \%)\end{array}$ \\
\hline $\begin{array}{l}\text { Allen, M., et al. Stronger together: Strategies to } \\
\text { protect local sovereignty, ecosystems, and } \\
\text { place-based communities from the global fossil } \\
\text { fuel trade. Marine Policy } 80: 168-176 .\end{array}$ & 2017 & & & & & $x$ & & \\
\hline $\begin{array}{l}\text { Dhillon, C. M. Using citizen science in } \\
\text { environmental justice: participation and } \\
\text { decision-making in a Southern California waste } \\
\text { facility siting conflict. Local Environment 22(12): } \\
\text { 1479-1496. }\end{array}$ & 2017 & & & & & $x$ & & \\
\hline $\begin{array}{l}\text { Kennedy, A., et al. "Taking away David's sling": } \\
\text { Environmental justice and land-use conflict in } \\
\text { extractive resource development. Local } \\
\text { Environment 22(8): 952-968. }\end{array}$ & 2017 & & & & & & & $X$ \\
\hline $\begin{array}{c}\text { Kaufman, A., et al. A Citizen Science and } \\
\text { Government Collaboration: Developing Tools to } \\
\text { Facilitate Community Air Monitoring. Environ } \\
\text { Justice 10(2): } 51-61 \text {. }\end{array}$ & 2017 & & & $x$ & & & & \\
\hline $\begin{array}{l}\text { Sanchez, H. K., et al. Confronting Power and } \\
\text { Environmental Injustice: Legacy Pollution and the } \\
\text { Timber Industry in Southern Mississippi. Society } \\
\text { \& Natural Resources 30(3): 347-361. }\end{array}$ & 2017 & & $x$ & & & & & \\
\hline $\begin{array}{l}\text { Wilson, S., et al. Soil Contamination in Urban } \\
\text { Communities Impacted by Industrial Pollution } \\
\text { and Goods Movement Activities. Environ Justice } \\
\text { 10(1): 16-22. }\end{array}$ & 2017 & & & & $x$ & & & \\
\hline
\end{tabular}


Table A1. Cont.

\begin{tabular}{|c|c|c|c|c|c|c|c|c|}
\hline \multirow[b]{2}{*}{ Included Articles } & & \multicolumn{7}{|c|}{ Community Engagement Continuum: Levels of Community Engagement } \\
\hline & & Outreach & Consultation & Involvement & Collaborate & $\begin{array}{c}\text { Shared } \\
\text { Leadership }\end{array}$ & $\begin{array}{l}\text { Community- } \\
\text { Led }\end{array}$ & $\begin{array}{l}\text { Unable to } \\
\text { Determine }\end{array}$ \\
\hline $\mathbf{N}(\%)$ & $\begin{array}{c}\text { Publication } \\
\text { Year }\end{array}$ & $\begin{array}{c}3 \\
(1.7 \%)\end{array}$ & $\begin{array}{c}5 \\
(8.6 \%)\end{array}$ & $\begin{array}{c}7 \\
(10.3 \%)\end{array}$ & $\begin{array}{c}15 \\
(27.6 \%)\end{array}$ & $\begin{array}{c}16 \\
(27.6 \%)\end{array}$ & $\begin{array}{c}11 \\
(22.4 \%)\end{array}$ & $\begin{array}{c}1 \\
(1.7 \%)\end{array}$ \\
\hline $\begin{array}{l}\text { Bruno, T. and W. Jepson. Marketisation of } \\
\text { environmental justice: U.S. EPA environmental } \\
\text { justice showcase communities project in Port } \\
\text { Arthur, Texas. Local Environment 23(3): 276-292. }\end{array}$ & 2018 & & & & $x$ & & & \\
\hline
\end{tabular}




\section{References}

1. Chavis, B. The historical significance and challenges of the first national people of color environmental leadership summit. In Proceedings of the First National People of Color Environmental Leadership Summit, Washington, DC, USA, 24-27 October 1991.

2. Bernier, C.J. Almost Everything You Need to Know about Environmental Justice. Available online: http://www.ucc.org/justice_ advocacy_resources_pdfs_environmental-justice_environmental-justice (accessed on 15 January 2022).

3. Bullard, R.D.; Mohai, P.; Saha, R.; Wright, B. Toxic Wastes and Race at Twenty, 1987-2007: A Report Prepared for the United Church of Christ Justice \& Witness Ministries; United Church of Christ: Cleveland, OH, USA, 2007.

4. Agyeman, J. Constructing environmental (in) justice: Transatlantic tales. Environ. Politics 2002, 11, 31-53. [CrossRef]

5. Bullard, R.D. Growing Smarter [Electronic Resource]: Achieving Livable Communities, Environmental Justice, and Regional Equity; MIT Press: Cambridge, MA, USA, 2007.

6. Environmental Protection Agency. Environmental Justice-About EJ 2020. Available online: https://www.epa.gov/ environmentaljustice/about-ej-2020 (accessed on 15 January 2022).

7. Schlosberg, D. Theorising environmental justice: The expanding sphere of a discourse. Environ. Politics 2013, 22, 37-55. [CrossRef]

8. Agyeman, J.; Schlosberg, D.; Craven, L.; Matthews, C. Trends and directions in environmental justice: From Inequity to everyday life, community, and just sustainabilities. Annu. Rev. Environ. Resour. 2016, 41, 321-340. [CrossRef]

9. Walker, G. Beyond distribution and proximity: Exploring the multiple spatialities of environmental justice. Antipode 2009, 41, 614-636. [CrossRef]

10. Gottlieb, R.; Joshi, A. Food Justice; MIT Press: Cambridge, MA, USA, 2010.

11. Finney, C. Black Faces, White Spaces: Reimagining the Relationship of African Americans to the Great Outdoors; UNC Press Books: Chapel Hill, NC, USA, 2014.

12. Schlosberg, D.; Collins, L.B. From environmental to climate justice: Climate change and the discourse of environmental justice. Wiley Interdiscip. Rev. Clim. Chang. 2014, 5, 359-374. [CrossRef]

13. Schlosberg, D.; Carruthers, D. Indigenous struggles, environmental justice, and community capabilities. Glob. Environ. Politics 2010, 10, 12-35. [CrossRef]

14. Rowan, G.T.; Fridgen, C. Brownfields and environmental justice: The threats and challenges of contamination. Environ. Pract. 2003, 5, 58-61. [CrossRef]

15. Ringquist, E.J. Assessing evidence of environmental inequities: A meta-analysis. J. Policy Anal. Manag. 2005, 24, 223-247. [CrossRef]

16. Di Chiro, G. Living environmentalisms: Coalition politics, social reproduction, and environmental justice. Environ. Politics 2008, 17, 276-298. [CrossRef]

17. Sze, J. Defining and contesting environmental justice: Socio-natures and the politics of scale in the delta. In Spaces of Environmental Justice; Wiley: Hoboken, NJ, USA, 2010. [CrossRef]

18. Whyte, K.P. The recognition dimensions of environmental justice in Indian country. Environ. Justice 2011, 4, 199-205. [CrossRef]

19. United Church of Christ Commission for Racial Justice. Toxic Wastes and Race in the United States: A National Report on the Racial and Socio-Economic Characteristics of Communities with Hazardous Waste Sites; Public Data Access: Miami, FL, USA, 1987.

20. Bryant, B.; Mohai, P. Race and the incidence of environmental hazards: A time for discourse. Politics Life Sci. 1995, 14, 111-113.

21. Brown, P. Race, class, and environmental health: A review and systematization of the literature. Environ. Res. 1995, 69, 15-30. [CrossRef] [PubMed]

22. Huang, H.; Tornero-Velez, R.; Barzyk, T.M. Associations between socio-demographic characteristics and chemical concentrations contributing to cumulative exposures in the United States. J. Expo. Sci. Environ. Epidemiol. 2017, 27, 544-550. [CrossRef] [PubMed]

23. Prüss-Üstün, A.; Corvalán, C. Preventing disease through healthy environments. In Towards an Estimate of the Environmental Burden of Disease; World Health Organization: Geneva, Switzerland, 2006.

24. Bullard, R.D. Dumping in Dixie: Race, Class, and Environmental Quality, 3rd ed.; Routledge: Oxfordshire, UK, 1990. [CrossRef]

25. Zou, B.; Peng, F.; Wan, N.; Mamady, K.; Wilson, G.J. Spatial cluster detection of air pollution exposure inequities across the United States. PLoS ONE 2014, 9, e91917. [CrossRef]

26. Mohai, P.; Saha, R. Reassessing racial and socioeconomic disparities in environmental justice research. Demography 2006, 43 , 383-399. [CrossRef]

27. Lee, C. Environmental justice: Building a unified vision of health and the environment. Environ. Health Perspect. 2002, 110 (Suppl. S2), 141-144. [CrossRef]

28. Hajat, A.; Hsia, C.; O’Neill, M.S. Socioeconomic disparities and air pollution exposure: A global review. Curr. Environ. Health Rep. 2015, 2, 440-450. [CrossRef]

29. Wilson, S.M. Environmental justice movement: A review of history, research, and public health issues. J. Public Manag. Soc. Policy 2010, 16, 19-50.

30. Park, Y.M.; Kwan, M.P. Multi-contextual segregation and environmental justice research: Toward fine-scale spatiotemporal approaches. Int. J. Environ. Res. Public Health 2017, 14, 1205. [CrossRef]

31. Solomon, G.M.; Morello-Frosch, R.; Zeise, L.; Faust, J.B. Cumulative environmental impacts: Science and Policy to protect communities. Annu. Rev. Public Health 2016, 37, 83-96. [CrossRef] 
32. Adamkiewicz, G.; Zota, A.R.; Fabian, M.P.; Chahine, T.; Julien, R.; Spengler, J.D.; Levy, J.I. Moving environmental justice indoors: Understanding structural influences on residential exposure patterns in low-income communities. Am. J. Public Health 2011, 101 (Suppl. S1), S238-S245. [CrossRef] [PubMed]

33. Morello-Frosch, R.; Zuk, M.; Jerrett, M.; Shamasunder, B.; Kyle, A.D. Understanding the cumulative impacts of inequalities in environmental health: Implications for policy. Health Aff. 2011, 30, 879-887. [CrossRef] [PubMed]

34. N'Dri, L.A.; White-Newsome, J.L.; Corbin-Mark, C.D.; Shepard, P.M. The invisible threat: Bisphenol-A and phthalates in environmental justice communities. Environ. Justice 2015, 8, 15-19. [CrossRef]

35. Ramirez-Andreotta, M.D.; Brody, J.G.; Lothrop, N.; Loh, M.; Beamer, P.I.; Brown, P. Improving environmental health literacy and justice through environmental exposure results communication. Int. J. Environ. Res. Public Health 2016, 13, 690. [CrossRef]

36. Anderson, L.M.; Adeney, K.L.; Shinn, C.; Safranek, S.; Buckner-Brown, J.; Krause, L.K. Community coalition-driven interventions to reduce health disparities among racial and ethnic minority populations. Cochrane Database Syst. Rev. 2015, 6, Cd009905. [CrossRef]

37. Crocker, D.D.; Kinyota, S.; Dumitru, G.G.; Ligon, C.B.; Herman, E.J.; Ferdinands, J.M.; Hopkins, D.P.; Lawrence, B.M.; Sipe, T.A. Effectiveness of home-based, multi-trigger, multicomponent interventions with an environmental focus for reducing asthma morbidity: A community guide systematic review. Am. J. Prev. Med. 2011, 41, S5-S32. [CrossRef]

38. Nurmagambetov, T.A.; Barnett, S.B.; Jacob, V.; Chattopadhyay, S.K.; Hopkins, D.P.; Crocker, D.D.; Dumitru, G.G.; Kinyota, S. Economic value of home-based, multi-trigger, multicomponent interventions with an environmental focus for reducing asthma morbidity a community guide systematic review. Am. J. Prev. Med. 2011, 41, S33-S47. [CrossRef]

39. Rehfuess, E.A.; Bartram, J. Beyond direct impact: Evidence synthesis towards a better understanding of effectiveness of environmental health interventions. Int. J. Hyg. Environ. Health 2014, 217, 155-159. [CrossRef]

40. Balazs, C.L.; Morello-Frosch, R. The three R's: How community based participatory research strengthens the rigor, relevance and reach of science. Environ. Justice 2013, 6, 9-16. [CrossRef]

41. Minkler, M.; Vásquez, V.B.; Tajik, M.; Petersen, D. Promoting Environmental Justice Through Community-Based Participatory Research: The Role of Community and Partnership Capacity. Health Educ. Behav. 2008, 35, 119-137. Available online: http:/ / www.jstor.org/stable/45055236 (accessed on 15 January 2022). [CrossRef]

42. McOliver, C.A.; Camper, A.K.; Doyle, J.T.; Eggers, M.J.; Ford, T.E.; Lila, M.A.; Berner, J.; Campbell, L.; Donatuto, J. Communitybased research as a mechanism to reduce environmental health disparities in american Indian and alaska native communities. Int. J. Environ. Res. Public Health 2015, 12, 4076-4100. [CrossRef] [PubMed]

43. Parker, E.A.; Chung, L.K.; Israel, B.A.; Reyes, A.; Wilkins, D. Community organizing network for environmental health: Using a community health development approach to increase community capacity around reduction of environmental triggers. J. Prim. Prev. 2010, 31, 41-58. [CrossRef] [PubMed]

44. Cohen, A.K.; Lopez, A.; Malloy, N.; Morello-Frosch, R. Surveying for environmental health justice: Community organizing applications of community-based participatory research. Environ. Justice 2016, 9, 129-136. [CrossRef]

45. Dhillon, C.M. Using citizen science in environmental justice: Participation and decision-making in a Southern California waste facility siting conflict. Local Environ. 2017, 22, 1479-1496. [CrossRef]

46. Dressel, A.; Anderko, L.; Koepsel, B. The westlawn partnership for a healthier environment: Promoting environmental justice and building community capacity. Environ. Justice 2013, 6, 127-132. [CrossRef]

47. Emmett, E.A.; Desai, C. Community first communication: Reversing information disparities to achieve environmental justice. Environ. Justice 2010, 3, 79-84. [CrossRef]

48. Gonzalez, P.A.; Minkler, M.; Garcia, A.P.; Gordon, M.; Garzon, C.; Palaniappan, M.; Prakash, S.; Beveridge, B. Community-based participatory research and policy advocacy to reduce diesel exposure in West Oakland, California. Am. J. Public Health 2011, 101, S166-S175. [CrossRef]

49. Kegler, M.C.; Rigler, J.; Ravani, M.K. Using network analysis to assess the evolution of organizational collaboration in response to a major environmental health threat. Health Educ. Res. 2010, 25, 413-424. [CrossRef]

50. Minkler, M.; Garcia, A.P.; Williams, J.; LoPresti, T.; Lilly, J. Si se puede: Using participatory research to promote environmental justice in a Latino community in San Diego, California. J. Urban Health Bull. N. Y. Acad. Med. 2010, 87, 796-812. [CrossRef]

51. Sadd, J.; Morello-Frosch, R.; Pastor, M.; Matsuoka, M.; Prichard, M.; Carter, V. The truth, the whole truth, and nothing but the ground-truth: Methods to advance environmental justice and researcher-community partnerships. Health Educ. Behav. Off. Publ. Soc. Public Health Educ. 2014, 41, 281-290. [CrossRef]

52. Stedman-Smith, M.; McGovern, P.M.; Peden-McAlpine, C.J.; Kingery, L.R.; Draeger, K.J. Photovoice in the red river basin of the north: A systematic evaluation of a community-academic partnership. Health Promot. Pract. 2012, 13, 599-607. [CrossRef] [PubMed]

53. Tajik, M.; Minkler, M. Environmental justice research and action: A case study in political economy and community-academic collaboration. Int. Q. Community Health Educ. 2006, 26, 213-231. [CrossRef] [PubMed]

54. Vasquez, V.B.; Minkler, M.; Shepard, P. Promoting environmental health policy through community based participatory research A case study from Harlem, New York. J. Urban Health Bull. N. Y. Acad. Med. 2006, 83, 101-110. [CrossRef]

55. Williams, E.M.; Anderson, J.; Lee, R.; White, J.; Hahn-Baker, D. Behind the fence forum theater: An arts performance partnership to address lupus and environmental justice. New Solut. J. Environ. Occup. Health Policy NS 2009, 19, 467-479. [CrossRef] 
56. Wilson, S.M.; Wilson, O.R.; Heaney, C.D.; Cooper, J. Use of EPA collaborative problem-solving model to obtain environmental justice in North Carolina. Prog. Community Health Partnersh. Res. Educ. Action 2007, 1, 327-337. [CrossRef]

57. Mansyur, C.L.; Jeng, H.A.; Holloman, E.; DeBrew, L. Using community-based participatory research to identify environmental justice issues in an inner-city community and inform urban planning. Fam. Community Health 2016, 39, 169-177. [CrossRef]

58. Staples, L. Community organizing for social justice: Grassroots groups for power. Soc. Work. Groups 2012, 35, 287-296. [CrossRef]

59. Goodman, R.M.; Speers, M.A.; McLeroy, K.; Fawcett, S.; Kegler, M.; Parker, E.; Smith, S.R.; Sterling, T.D.; Wallerstein, N. Identifying and defining the dimensions of community capacity to provide a basis for measurement. Health Educ. Behav. Off. Publ. Soc. Public Health Educ. 1998, 25, 258-278. [CrossRef]

60. Freudenberg, N.; Pastor, M.; Israel, B. Strengthening community capacity to participate in making decisions to reduce disproportionate environmental exposures. Am. J. Public Health 2011, 101 (Suppl. S1), S123-S130. [CrossRef]

61. Williamson, D.H.; Yu, E.X.; Hunter, C.M.; Kaufman, J.A.; Komro, K.; Jelks, N.T.O.; Johnson, D.A.; Gribble, M.O.; Kegler, M.C. A scoping review of capacity-building efforts to address environmental justice concerns. Int. J. Environ. Res. Public Health 2020, 17, 3765. [CrossRef]

62. Honeycutt, S.; Leeman, J.; McCarthy, W.J.; Bastani, R.; Carter-Edwards, L.; Clark, H.; Garney, W.; Gustat, J.; Hites, L.; Nothwehr, F. Evaluating policy, systems, and environmental change interventions: Lessons learned from CDC's prevention research centers. Prev. Chronic Dis. 2015, 12, E174. [CrossRef] [PubMed]

63. Comprehensive Cancer Control National Partners. The Policy, Systems, and Environmental Change (PSE) Resource Guide; Comprehensive Cancer Control National Partners: Atlanta, GA, USA, 2015.

64. National Center for Research Resources. Clinical and translational science awards consortium community engagement key function committee task force on the principles of community engagement. In The Principles of Community Engagement, 2nd ed.; National Institutes of Health, Centers for Disease Control and Prevention, and The Agency for Toxic Substances and Disease Registry: Bethesda, MD, USA, 2011.

65. Allen, B.L. Saving St. Gabriel: The emergence of a new African-American town. Contemp. Justice Rev. $2001,4,145$.

66. Bell, S.E. Bridging activism and the academy: Exposing environmental injustices through the feminist ethnographic method of photovoice. Hum. Ecol. Rev. 2015, 21, 27-58. [CrossRef]

67. Brown, P.; Mayer, B.; Zavestoski, S.; Luebke, T.; Mandelbaum, J.; McCormick, S. The health politics of asthma: Environmental justice and collective illness experience in the United States. Soc. Sci. Med. 2003, 57, 453-464. [CrossRef]

68. Haynes, E.N.; Beidler, C.; Wittberg, R.; Meloncon, L.; Parin, M.; Kopras, E.J.; Succop, P.; Dietrich, K.N. Developing a bidirectional academic-community partnership with an Appalachian-American community for environmental health research and risk communication. Environ. Health Perspect. 2011, 119, 1364-1372. [CrossRef]

69. Higman, K.; Servatius, C.; Webber, W.L.; McDonald, T. Using the PACE EH model to mobilize communities to address local environmental health issues-A case study in Island county, Washington. J. Environ. Health 2007, 70, 37-41.

70. Kegler, M.C.; Malcoe, L.H.; Fedirko, V. Primary prevention of lead poisoning in rural native American children behavioral outcomes from a community-based intervention in a former mining region. Fam. Community Health 2010, 33, 32-43. [CrossRef]

71. Kreger, M.; Sargent, K.; Arons, A.; Standish, M.; Brindis, C.D. Creating an environmental justice framework for policy change in childhood asthma: A grassroots to treetops approach. Am. J. Public Health 2011, 101 (Suppl. S1), S208-S216. [CrossRef]

72. Miller, P.K.; Waghiyi, V.; Welfinger-Smith, G.; Byrne, S.C.; Kava, J.; Gologergen, J.; Eckstein, L.; Scrudato, R.; Chiarenzelli, J.; Carpenter, D.O.; et al. Community-based participatory research projects and policy engagement to protect environmental health on St Lawrence Island, Alaska. Int. J. Circumpolar Health 2013, 72, 21656. [CrossRef]

73. Sullivan, J.; Parras, J. Environmental justice and augusto boal's theatre of the oppressed: A unique community tool for outreach, communication, education and advocacy. Theory Action 2008, 1, 20-39. [CrossRef]

74. Wier, M.; Sciammas, C.; Seto, E.; Bhatia, R.; Rivard, T. Health, traffic, and environmental justice: Collaborative research and community action in San Francisco, California. Am. J. Public Health 2009, 99 (Suppl. S3), S499-S504. [CrossRef] [PubMed]

75. Wilson, S.; Aber, A.; Ravichandran, V.; Wright, L.; Muhammad, O. Soil contamination in urban communities impacted by industrial pollution and goods movement activities. Environ. Justice 2017, 10, 16-22. [CrossRef]

76. Allen, M.; Bird, S.; Breslow, S.; Dolšak, N. Stronger together: Strategies to protect local sovereignty, ecosystems, and place-based communities from the global fossil fuel trade. Mar. Policy 2017, 80, 168-176. [CrossRef]

77. Barry, J.M. "A small group of thoughtful, committed citizens": Women's activism, environmental justice, and the coal river mountain watch. Environ. Justice 2008, 1, 25-33. [CrossRef]

78. Garcia, A.P.; Wallerstein, N.; Hricko, A.; Marquez, J.N.; Logan, A.; Nasser, E.G.; Minkler, M. The (trade, health, environment) impact project: A community-based participatory research environmental justice case study. Environ. Justice 2013, 6, 17-26. [CrossRef]

79. Grineski, S.E. Local struggles for environmental justice: Activating knowledge for change. J. Poverty 2006, 10, 25-49. [CrossRef]

80. Johnson, G.S. Grassroots Activism in Louisiana. Humanit. Soc. 2005, 29, 285-304. [CrossRef]

81. Kaup, B.Z.; Casey, D. Coalition of injustice? Bodies, business, and the biosphere in struggles against unwanted land uses. Environ. Politics 2016, 25, 494-512. [CrossRef]

82. Loh, P.; Sugerman-Brozan, J.; Wiggins, S.; Noiles, D.; Archibald, C. From asthma to airbeat. Environ. Health Perspect. Suppl. 2002, 110, 297. [CrossRef] 
83. Minkler, M. Linking science and policy through community-based participatory research to study and address health disparities. Am. J. Public Health 2010, 100, S81-S87. [CrossRef]

84. Robinson, E.E. Sharing stories. Humanit. Soc. 2016, 40, 442-461. [CrossRef]

85. Schwartz, N.A.; von Glascoe, C.A.; Torres, V.; Ramos, L.; Soria-Delgado, C. "Where they (live, work and) spray": Pesticide exposure, childhood asthma and environmental justice among Mexican-American farmworkers. Health Place 2015, $32,83-92$. [CrossRef] [PubMed]

86. Senier, L.; Hudson, B.; Fort, S.; Hoover, E.; Tillson, R.; Brown, P. Brown superfund basic research program: A multistakeholder partnership addresses real-world problems in contaminated communities. Environ. Sci. Technol. 2008, 42, 4655-4662. [CrossRef]

87. Blodgett, A.D. An analysis of pollution and community advocacy in 'Cancer Alley': Setting an example for the environmental justice movement in St James Parish, Louisiana. Local Environ. 2006, 11, 647-661. [CrossRef]

88. Brown, P.; Mastersonallen, S. The toxic-waste movement-A new-type of activism. Soc. Nat. Resour. 1994, 7, 269-287. [CrossRef]

89. Bruno, T.; Jepson, W. Marketisation of environmental justice: U.S. EPA environmental justice showcase communities project in Port Arthur, Texas. Local Environ. 2018, 23, 276-292. [CrossRef]

90. Bullard, R.D.; Wright, B.H. The quest for environmental equity-Mobilizing the African-American community for social-change. Soc. Nat. Resour. 1990, 3, 301-311. [CrossRef]

91. Capek, S.M. Environmental justice, regulation, and the local-community. Int. J. Health Serv. 1992, 22, 729-746. [CrossRef]

92. Čapek, S.M. The "environmental justice" frame: A conceptual discussion and an application. Soc. Probl. 1993, 40, 5-24. [CrossRef]

93. Corburn, J. Combining community-based research and local knowledge to confront asthma and subsistence-fishing hazards in Greenpoint/Williamsburg, Brooklyn, New York. Environ. Health Perspect. 2002, 110 (Suppl. S2), 241-248. [CrossRef]

94. Drury, R.T. Moving a mountain: The struggle for environmental justice in southeast Los Angeles. Environ. Law Rep. News Anal. 2008, 38, 10338-10346.

95. Hines, R.I. The price of pollution: The struggle for environmental justice in Mossville, Louisiana. West. J. Black Stud. 2015, 39, 198-208.

96. Jacobs, J. A Community organizing case study: An analysis of cap-it's strategy to prevent the location of a toxic waste incinerator in their community. Int. Q. Community Health Educ. 1992, 13, 253-263. [CrossRef] [PubMed]

97. Schelly, D.; Stretesky, P.B. An analysis of the "path of least resistance" argument in three environmental justice success cases. Soc. Nat. Resour. 2009, 22, 369-380. [CrossRef]

98. Sherman, D.J. Disruption or convention? A process-based explanation of divergent repertoires of contention among opponents to low-level radioactive waste disposal sites. Soc. Mov. Stud. 2008, 7, 265-280. [CrossRef]

99. Sicotte, D. Don't waste us: Environmental justice through community participation in urban planning. Environ. Justice 2010, 3, 7-11. [CrossRef]

100. White, B.M.; Hall, E.S. Perceptions of environmental health risks among residents in the "Toxic Doughnut": Opportunities for risk screening and community mobilization. BMC Public Health 2015, 15, 1230. [CrossRef]

101. Green, L.; Fullilove, M.; Evans, D.; Shepard, P. “Hey, mom, thanks!": Use of focus groups in the development of place-specific materials for a community environmental action campaign. Environ. Health Perspect. 2002, 110 (Suppl. S2), 265-269. [CrossRef]

102. Rohlman, D.; Syron, L.; Hobbie, K.; Anderson, K.A.; Scaffidi, C.; Sudakin, D.; Peterson, E.S.; Waters, K.M.; Haynes, E.; Arkin, L.; et al. A community-based approach to developing a mobile device for measuring ambient air exposure, location, and respiratory health. Environ. Justice 2015, 8, 126-134. [CrossRef]

103. Sanchez, H.K.; Adams, A.E.; Shriver, T.E. Confronting power and environmental injustice: Legacy pollution and the timber industry in southern Mississippi. Soc. Nat. Resour. 2017, 30, 347-361. [CrossRef]

104. Spencer-Hwang, R.; Soret, S.; Valladares, J.; Torres, X.; Pasco-Rubio, M.; Dougherty, M.; Kim, W.; Montgomery, S. Strategic partnerships for change in an environmental justice community: The enrrich study. Prog. Community Health Partnersh. Res. Educ. Action 2016, 10, 541-550. [CrossRef] [PubMed]

105. Brickle, M.B.; Evans-Agnew, R. Photovoice and youth empowerment in environmental justice research: A pilot study examining woodsmoke pollution in a pacific northwest community. J. Community Health Nurs. 2017, 34, 89-101. [CrossRef] [PubMed]

106. Jiao, Y.; Bower, J.K.; Im, W.; Basta, N.; Obrycki, J.; Al-Hamdan, M.Z.; Wilder, A.; Bollinger, C.E.; Zhang, T.; Hatten, L.S.; et al. Application of citizen science risk communication tools in a vulnerable urban community. Int. J. Environ. Res. Public Health 2015, 13, 11. [CrossRef] [PubMed]

107. Kaufman, A.; Williams, R.; Barzyk, T.; Greenberg, M.; O’Shea, M.; Sheridan, P.; Hoang, A.; Ash, C.; Teitz, A.; Mustafa, M.; et al. A citizen science and government collaboration: Developing tools to facilitate community air monitoring. Environ. Justice 2017, 10, 51-61. [CrossRef] [PubMed]

108. Wing, S.; Horton, R.A.; Muhammad, N.; Grant, G.R.; Tajik, M.; Thu, K. Integrating epidemiology, education, and organizing for environmental justice: Community health effects of industrial hog operations. Am. J. Public Health 2008, 98, 1390-1397. [CrossRef]

109. Wilson, S.; Aber, A.; Wright, L.; Vivek, R. A review of community-engaged research approaches used to achieve environmental justice and eliminate disparities. In The Routledge Handbook of Environmental Justice; Holifield, R., Chakraborty, J., Walker, G., Eds.; Routledge: Oxfordshire, UK, 2017; pp. 283-296. 
110. Israel, B.A.; Krieger, J.; Vlahov, D.; Ciske, S.; Foley, M.; Fortin, P.; Guzman, J.R.; Lichtenstein, R.; McGranaghan, R.; Palermo, A.G.; et al. Challenges and facilitating factors in sustaining community-based participatory research partnerships: Lessons learned from the Detroit, New York City and Seattle Urban Research Centers. J. Urban Health Bull. N. Y. Acad. Med. 2006, 83, 1022-1040. [CrossRef] [PubMed]

111. Eldredge, L.K.B.; Markham, C.M.; Ruiter, R.A.; Kok, G.; Parcel, G.S. Planning Health Promotion Programs: An Intervention Mapping Approach; John Wiley \& Sons: Flatbush, NY, USA, 2016. 